\title{
Allal Al-Fassi's Utopia: Liberalism and Democracy within the Revivalist System of Thought
}

\author{
Hamza Salih \\ Mohamed V University - Rabat - Morocco \\ Salih.hamza.hfm@gmail.com
}

DOI: http://doi.org/ 10.36892/ijlls.v3i3.705

\begin{tabular}{ll} 
Received: & Abstract \\
09/09/2021 & This paper examines the political writings of the Moroccan nationalist Allal \\
Al-Fassi (1910-1974). It argues that there exists a considerable political \\
Accepted: & tendency in these writings with excessive utilisation of jargon related to \\
& liberalism and political theory. In his intellectual and political project, Al- \\
& Fassi theorises about the possibility of creating a modern state on solid \\
democratic and liberal foundations. Yet, however legitimate and seemingly & liberal his theorisation might seem, the paper argues that the formation of a \\
\hline Keywords: & liberal state and a democratic society appears to be a mere dream given the \\
Allal Al-Fassi, & fact that Al-Fassi grounds his conceptions within the Salafist and revivalist \\
Nationalism, & intellectual systems. Reading between the lines of his political works, \\
Liberalism, Salafism, & nevertheless, reveals the dominance of Salafist intellections which deem the \\
Maqassid al-Sharia. & past and Islam as restorative in attaining a modern renaissance, at the \\
& political, economic, and cultural levels. This work, thus, problematizes three \\
central points: the political tendency of Al-Fassi's project, his religious and \\
Salafist remnants and conceptions, and finally the possible ideological \\
implications and interests that Al-Fassi seems to defend.
\end{tabular}

\section{INTRODUCTION}

This paper examines the political writings of the Moroccan nationalist Allal Al-Fassi (1910-1974) and his conception of modernity and formulations of modernisation. It focuses on his intellectual project and prolific political writings in relation to the West as Other and modernity as an idea as its central endeavour. It argues that there exists a considerable political tendency in these writings with excessive utilisation of jargon related to liberalism and political theory. In his intellectual and political project, Al-Fassi theorises about the possibility of creating a modern state on solid democratic and liberal foundations. Yet, however legitimate and seemingly liberal his theorisation might seem, the paper argues that the formation of a liberal state and a democratic society appears to be a mere dream given the fact that Al-Fassi grounds his conceptions within the Salafist and revivalist intellectual systems.

Because of the novel historical and political conditions prevailing during colonial days (1912-1956), the Moroccan nationalists demonstrated their awareness of the Western "political weapons," and thus advocated various political interpretations of democracy and liberalism. In such a novel context, Al-Fassi, questioned the feasibility and reliability of democracy and liberalism to a culture in which Islam and Sharia were deeply-rooted. His questioning gave rise to a distinct political engagement with modernity since the Moroccan 
nationalists, including Al-Fassi, did not reject outright European liberalism in spite of the incongruence existing in their minds between the European states as colonisers on the one hand and Europe as a possible cultural and political model. Al-Fassi's writings substantiated his immense courage to consciously consider the West as a paragon from which Moroccan society could adopt valuable modern tenets, demarcating him as a liberal thinker. Reading between the lines of his political works, however, reveals the dominance of Salafist intellections which deem the past and Islam as restorative in attaining a modern renaissance, at the political, economic, and cultural levels.

To develop these arguments, this paper begins by highlighting the general political orientation and understanding of modernity of the Moroccan nationalist al-Fassi. It examines the extent to which Al-Fassi's intellectual project can be described as politically engaged with liberal and democratic ideals. Since only the intellectual's attitude towards the Sharia, in Laroui's words, can determine his distance from liberalism, the second challenge in this paper is to decipher the remnants of his religious and cultural understanding of modernisation. To what extent has Salafism influenced his political conceptions both as an intellectual and as a political leader? The study revolves then around how modern and liberal concepts and structures like the political party, democracy and liberalism take a particular religious and Salafist form to serve modern purposes. Al-Fassi endeavoured, in almost the same way as Mohammed Abduh did, to moderate introducing new liberal ideas to a conservative society. Finally, this paper scrutinises the ideological implications of Al-Fassi's political project. Simply put, it studies the extent to which Al-Fassi's political perception and reception of modernity hides certain ideological interests related to the position of his political party in the Moroccan political scene, to historiography, and most importantly to theorising about the so-called "modern Moroccan renaissance." This work, thus, sheds light on three central points: the political tendency of Al-Fassi's project, his religious and Salafist remnants and conceptions, and finally the possible ideological implications and interests that Al-Fassi seems to defend.

\section{ALLAL AL-FASSI AND SALAFISM: HISTORICAL CONSIDERATIONS}

A study encompassing all the various political, pedagogical, and intellectual trends of a prolific thinker like Al-Fassi seems daunting. Abdelkrim Ghallab (1974) notes that "it is so toilsome for a writer to write about Allal Al-Fassi if he does not possess a real infinite patience to follow this man in his ideas, his plans, and his political, intellectual and social orientations" (1974, p. 3). Due to Al-Fassi's apparent political and social influence on large masses and his spawning political, religious, and pedagogical writings, it becomes hard to delimit the scope of the theoretical examination of his work. The historical conditions of the era in which Al-Fassi lived made him a militant nationalist and intellectual with diverse interests. Al-Fassi lived in a context in which colonisation vigorously challenged the systems of thought of Moroccan intellectual elite by threatening national oneness, as well as civilisational, cultural, and religious identity. In fact, the Moroccan Makhzani elite failed to respond positively to the calls of modernisation, and hence an impending crisis prevailed over Morocco in the late nineteenth century and the beginning of the twentieth. This deepened the state of civilisational stagnancy and generated an abject and costly failure in the effort to avoid colonial intervention in Morocco.

The beginning of the twentieth century was the ultimate culmination of the various setbacks at all levels in the nineteenth century. Laroui (2009) links the main historical turning points, including colonisation and the emergence of nationalism to their cultural and social origins in the nineteenth century. "The truth was that France and Spain did not put us [Moroccans] through the mill until we became but a mere carrion which had been dead as a doornail for so long and whose disgusting malodour hang in the air outside the borders" (AlAlaoui, 2009, pp. 16-17). The shaky political, social, and intellectual grounds of Morocco at 
the beginning of the last century paved the way for the colonisation of the nation in 1912. AlFassi belonged to a generation who took the helm of the nationalist ship in this historical context and led political resistance against colonisation. With the exception of a few graduates of French schools and universities, most of the leading figures of this generation graduated from al-Qarawiyin University in Fes. Al-Fassi himself received his licence (chahadat al- 'alimiya) from this university in 1932. It is between the walls of this religious centre that he shaped his personality and was acknowledged as a remarkable charismatic leader. In the late 1920s, Al-Fassi became, along with Hassan Ouazzani, the most influential founding father of the Comité d'action. This setting of Al-Qarawiyin also gave a fertile ground for Salafist thought to be extended and disseminated among the young pupils, including Al-Fassi. Some leading figures like Bouchaib Doukkali (1878-1937) and Mohamed Ben Arbi Al-Alaoui (1880-1964) duplicated the Eastern experience led by Djamal Ad-Din Al-Afghani (I839-1897), Mohamed Abduh (1849-1905), and Mohammed Rachid Reda (1865-1935). Al-Fassi was the pupil of Ben Arbi Al-Alaoui whose "Salafism was practical instead of being merely theoretical based on the Koran and the Sunna and the comparison of the conceptions of these texts and the daily life in Morocco" (Ghallab, 1991, p.14). This thought took the form of a religious reformist movement against zawāya and bida'e and at the same time a political movement of resistance against the coloniser. The young generation of nationalists found themselves in this religious, political and intellectual milieu, and hence their thoughts and actions were shaped according to these new historical parameters, namely education from Al-Qarawiyin, Salafism, and colonisation.

an essential education for the personality of the Muslims on the principles that Islam advocated as the sole guarantee for the well-being of the Umma both in this world and the otherworldly. It is a movement that targets the purification of the personal efforts for the collective well-being and common good of society (Al Fassi, 2003, p. 156). ${ }^{1}$

For Al-Fassi, the problem resides basically in religious affairs of the community. The present uncertainties necessitate an urgent religious reformism. The central line of argumentation of Al-Fassi in this sense implies that the national economic and political liberation can be guaranteed by the safeguarding and preservation of religion from external dangers manifested in colonialism and internal ones exemplified by zawāya, bida' $e$, and the mystical Islam in general. The political action in itself should serve this very objective of "defending Islam and the Umma," in Al-Fassi's words. Although Al-Fassi's ideological critique is directed towards the new colonial realities like dependence, social misery, exploitation and underdevelopment, his main interest centralises itself on the question of morals and the gradual loss of authenticity. His critique revolves around the so-called "retour aux sources." Notwithstanding, this can never deny the considerable weight of Al-Fassi's thought and the partially liberal calls he expresses in his political understanding of the idea of modernity.

\section{ALLAL AL-FASSI'S POLITICAL THOUGHT: LIBERALISM ISLAMISED}

Most of the works of Al-Fassi reveal a deep concern with the political question and with the liberal and democratic tenets that the state might advocate for, by establishing what he calls "Moroccan renaissance." He does not see Europe and modernity from a purely traditional perspective as he has no qualms whatsoever about calling Moroccans to benefit from British and French constitutional rule and institutional structures. In his an-Naqd al-

\footnotetext{
${ }^{1}$ We use this term, reformist Salafism (salafiya islahia) to designate the intellectual thought that flourished starting from the mid-nineteenth century in Egypt with Abduh, al-Afghani and Rachid Rida. It is totally different from the traditional Salafism germinating from Wahabism. Morocco itself knew this traditional Wahabist Salafism during the reign of Sultan Sulaymane (1799-1822).
} 
Dhati, he overtly numbers the various benefits of the constitutional monarchical system that the British adopt and argues for its utilitarian effects for the emerging Moroccan state. "Moroccan democracy," he writes, "should stand on a solid parliamentary system (Al-Fassi, pp. 129-130)." In so many passages of the book, he does not hide his deep, and sometimes sneaking, admiration for the way the British organise their political life on a parliamentary monarchy with a clear-cut separation of powers. He even recalls Montesquieu's theory of power to argue for the necessity of the separation of powers to guarantee a democratic political practice. ${ }^{2}$ Al-Fassi argues that "democracy in its very essence requires the division of political work among political practitioners since the centralisation of government and sovereignty in one hand or one political party will not lead to the empowerment of the governed" (2008, p. 131). It is no wonder that Al-Fassi heavily loads his political writings with political jargon related to the modern political theory, in general, and to liberalism, in particular. Concepts like democracy, liberalism, the public opinion, the separation of powers, the constitution, the parliamentary representation, state sovereignty, citizenship, liberty, modernity, and constitutional and institutional reforms appear repeatedly in Al-Fassi's political writings. The use of this jargon can never be innocent, as it formulates a focal point from which his intellectual project effloresces into explicit calls for the adoption of these various tenets.

Al-Fassi devotes much of his intellectual energy to ground the nationalist movement within a seemingly liberal discursive mainstream. He holds that an absolute necessity imposes itself on "the public opinion to fulfil a radical reform that makes the Umma sovereign over the State, while the people is given the right to manage its public affairs and to choose its own representatives by means of a constitutional reform that guarantees a democratic spirit of the political practice" (Al-Fassi, 1999, p. 10). Al-Fassi genealogically delves into many constitutional attempts advocated in Morocco before and during the colonial era in his Hafriate fi al-Haraka al-Dosstoriya fi Maghrib ma Qabla al-Himaya [Genealogy of Constitutional Movement in the Pre-Colonial Morocco]. In this book, he seems eager to study the constitutional experience of Morocco and look for the liberal remnants in many scattered constitutional projects. Al-Fassi considers the first draft of a constitution in modern Morocco submitted to Sultan Abdelaziz in 1906 as the first seed of a long struggle to ratify a constitution for the nation. He traces the development of this constitutional tendency from the 1906 constitution drafted by the Lebanese Abdelkrim Mourad and submitted to Sultan Abdelaziz, to the so-called al-bay 'a al-Hafidiya in 1908, to the constitutional project of Harakat Lissan al-Maghreb in 1908, and finally to Matalib alCha'eb al-Maghrebi given to the Sultan and The General Residency by the Comite d'action in 1934. "The blessing of constitution," as he often calls it, remains important for the renaissance of the nation. It presents itself like a social contract between "the governor and the governed which guarantees self-sovereignty of the people and leads to the preservation of harmony between the people and the Sultan, who would be a constitutional monarch adhering to willingness and sovereignty of the people" (1999, p. 20). He goes so far as to argue that Moroccans should strive for a liberating constitution as the traditional form of government was unable to bring about any concrete changes. For Al-Fassi, appointing ministers, as the Moroccan case demonstrates, "remains by any means sufficient to attain the desired reform with the effective participation of the people through its representatives who are responsible in front of the people" (1999, p. 11).

Al-Fassi's admiration for the constitution and its political utility for the development of the nation is unquestionable. He holds that constitution is one of the central rights of the Umma that the latter should fight for in order to come in terms with the challenges of modern times. Al-Fassi makes a request to the Sultan that "there might be no escape for His Majesty

\footnotetext{
${ }^{2}$ See for instance pages 130,131, 132, and 135 of An-Naqdad-Dhati.
} 
to make his Umma enjoy 'the blessing of constitution' and a House of Representatives and give it liberty of work and thought to guarantee certain utilitarian reform following the steps of the developed nations" (1999, p. 31). He equates in a sense the enactment of constitution and the advocacy of civic rights with the possibility of bringing about certain changes to the nation. Al-Fassi courageously reads the draft of Dosstour Lissan al-Maghreb proposed to Sultan Abdelhafid in 1908 as an insightful constitution that might have kept colonialism away from Morocco (1999, p. 38). Though it is too dreamy and romantic a reading, Al-Fassi believes in the utility of a constitution which highlights and guarantees personal liberty, citizenship, democracy and the right of the people to suggest to and supervise the government. To quote him at length, he says:

The right of the Umma to govern itself by itself goes in line of accordance with its right to independently manage its own affairs, and with its right to enjoy governmental stability and national autonomy ... to the point of the people's control over the work of the governors. This control is the right of every citizen, be they male or female and regardless of their intellectual or educational backgrounds and of their socio-economic status. This is because the enjoyment of the right of citizenship is sufficient for one to obtain all the rights of a citizen regardless of their religious, racial, or social differences. The willingness to give the people the right to supervision and suggestion requires a structured political organisation of the people's representative and parliamentary commissions based on democratic foundations (2008, pp. 1289).

Such quotes are numerous in Al-Fassi's political writings and are heavily loaded with political jargon that might be roughly categorised within the realms of the liberal thought. His reference to citizenship as the only measure to enjoy rights regardless of gender, social and racial differences breaks with the stratification of the state and society of the nineteenth century. In fact, he highlights the centrality of the people in a representational form of government, which can be seen as transcendental to the Islamic form of representation of $a h l$ al-halwa al-'aqd.

If the people's weight is central to a constitutional and democratic system, it is liberty of thought and action that brings democracy from the possible to the real. Al-Fassi contends that the Moroccan intellectuals and politicians have to advocate rational tendencies in different fields, including liberty of thought (2008, p. 54). He points out that Moroccans need "to accept rational principles which give the citizen the liberty of belief and liberty of thought, and this cannot be attained except through associations, political parties, and syndicates" (2008, p. 54). The idea of liberty of thought is highlighted here with some liberal dimensions that stress the importance of civil society to the emanation and realisation of the idea of liberty. This is reminiscent of the Weberian central postulation of the rationalisation and societalisation of society through civil society's institutions and bureaucracy. Therefore, Al-Fassi here combines rational principles with guaranteeing liberty which can be attained only within the structures and institutions of civil society. He even devotes a whole book entitled Al-Horiya [Liberty] to dig into and trace the evolution of the idea of liberty in Western thought by Western philosophers. He tries to problematise about this concept by referring to some ground-breaking Western philosophers who theorized liberty, including Aristotle, Descartes, Kant, Malebranche, Spinoza, Hobbes, Mill, de Tocqueville, Paine, and others. Liberty for Al-Fassi is mandatory to progress in knowledge and prior to nature. One of liberty's manifestations is the law revealing the general and public will by which citizens govern by themselves or by their representatives. ${ }^{3}$ Directing criticism to Rousseau who

${ }^{3}$ AL-Fassi, (N. D), Al-Horiya [Liberty] (Rabat: LajnatIhya' ethuratAllal al-Fassi) 49. 
considers the law as restricting people's liberty, Al-Fassi argues that the law remains a dissemination and grounding for the liberal spirit reflecting the public will, but never restricting the latter (Al-Horiya, p. 49). For Al-Fassi, "everything begins with and in liberty and ends with and in it" (Al-Horiya, p. 56).

To make a convincing reconciliation between private and public interests that has dominated long-standing debates within the Muslim 'alim-s, Al-Fassi argues that personal liberty of thought remains absolute because it is related to thought and its relation to willingness and reality. Civic liberty, which organises social life, revolves basically around the necessary rights organising human life with social existence (Al-Horiya, p. 58). To violate human liberty, including the national one, can be described as a dangerous human crime. AlFassi holds that human personal liberty guarantees the right of people to stay totally free without any violations which might transgress the free being of people. From a liberal perspective, Al-Fassi points out that the attainment of personal freedom can only be reached through guaranteeing political freedom. In this context, he appears keen on stressing the political aspect and extension of liberty. He defines political liberty as the freedom to work in the public space and to participate in governing the affairs of the nation, namely in administration, security, law enactment, education, and justice. Al-Fassi goes so far as to argue that the emergence and raison d'etre of the State is guaranteeing, generalising, and preserving personal freedom from discrimination by forcing citizens to abide by laws and regulations (Al-Horiya, p. 66). Both personal and political liberty cannot flourish in an authoritarian or totalitarian political system which centralises power and decision making in one hand that does not believe in the right of the people to enact laws and supervise their application. In a nutshell, Al-Fassi strongly defends his position with regards to the idea of liberty from a political perspective and argues that "every political system might bring about reforms and benefits. Political liberty could be achieved solely in the democratic political system in which the people govern themselves by themselves" (Al-Horiya, p. 67). The concept of liberty for this Moroccan nationalist constitutes the backbone of his intellectual project; liberty either pushes the nation forwards or pulls it backwards.

Notwithstanding, Al-Fassi calls his people to ponder the very meaning of liberty, both theoretically and practically. Quoting from Voltaire, he argues that liberty does not necessarily involve doing everything one wants to, but to prepare oneself for defending liberty as a guiding principle and to ceaselessly struggle for it (2008, p. 44). Al-Fassi extends his argument and states that:

For those who strive for liberty of thought and expression, they themselves need to initially be liberal and progressive. The rational doctrine which has triumphed throughout the world is inescapable and this is because of the efforts made by the prophets of thought and liberation and the sacrifices they made for the fulfilment of their liberal ideals. For us, however, we are heavily enchained and hence we need to liberally feel the necessity of shaking off our shackles. In fact, our intellectual elite still judges the world from a perspective that has been handed over from the past without any questioning. They cannot turn to reason and make it the supreme judge of our desire (2008, p. 52).

In this sense, liberty cannot become deeply-rooted into the systems and paradigms of thought of people unless it is grounded into intellectual structures. That is, before struggling for freedom of thought and expression, according to Al-Fassi, one has to position oneself within the progressive stream of rational foundations. By contrast, from his Salafist point of view, discussed below, ironically enough, Al-Fassi has no sanctions over the consideration of reason as the supreme and absolute authority of judgement over the present affairs, including the past turath (tradition) handed over from the past. Al-Fassi concludes a significant section of al-Naqdal-Dhati about the freedom of thought by stressing the fact that "we had no qualms 
about advocating the rational doctrine in many fields, including the right to freedom of thought" (2008, p. 54).

Al-Fassi's political writings disclose a liberal tendency linguistically unfolding in a political jargon full of liberal concepts. Reason and rationalisation can be considered as the cornerstones of the liberal thought. They should manifest in the social fabric of the community and in the political practice of the elite. By the same token, Al-Fassi esteems reason as the most efficient means to attain the purification of the prevailing culture from the remnants of dogmatism. "Let us trust reason and privilege its position," Al-Fassi writes, "and let us teach people how to think rationally; let the freedom of thought be an indispensable part of our beliefs ... This can be the best means for the emancipation of our societies from enslavement and for the protection of our intellectual elite from whatever biased calls which do not respect reason and do not believe in liberation" (2008, p. 55).

More significantly, he strongly advises his fellow readers to "liberate themselves from whatever authority other than that of reason and liberty so that we would emancipate public opinion from superstitions of the past and the idols of the present" (2008, p. 64). Al-Fassi heavily uses these concepts of freedom and reason to serve his political argumentation for the adoption of democracy and constitutional monarchy. He holds that democracy is the ultimate culmination of reason and freedom, and hence "the democratic style remains the best means for liberal expression of the general opinion ... If democracy designates the dominance of reason over our affairs, it is our ethical duty to highly elevate the status of reason, as the latter is the only protector from errors and selfish desires" (2008, p. 59). In fact, Al-Fassi links the free choice of the people in a democratic political system to the prevalence of reason and liberty since "life without the latter is death itself; existence without liberal thought is nothingness itself; and civilisation without liberating bases is but pre-historic savagery" (2008, p. 59).

With so rhetorical a language, he continues the amalgamation of liberty, freedom, and democracy into an inseparable continuum which guarantees the well-being of the people in a political system that strives for the common good. "Every political system that is not based on and grounded in liberty and equality", Al-Fassi writes, "ultimately leads to turmoil and uncertainty; and every political administration which does not work for the common good is but chaos; and every people who do not struggle for justice, freedom, and the prevalence of public common good are doomed to annihilation" (2008, p. 83). Although Al-Fassi's conclusions about liberty and liberal practice political might be considered valid to a great extent, it is legitimate to pose a pertinent question in this regard: to what extent does AlFassi's intellectual project escape being influenced by the remnants of his religious and cultural understanding of modernity? More specifically, to what extent are his intellectual project and political understanding of modernity a mere shrouding of a particular Salafist and religious ideology with the cover of modern and liberal concepts and structures like the political party, democracy and liberalism?

Arguing from the perspective of his theory of maqassid al-Sharia (purposes of the Sharia), Al-Fassi categorises politics and state-related affairs within the realm of the interests (maslahiyat). That is, the principles of government in Islam are grounded in the teachings of the Koran and the Sunna. Yet they are similarly conditioned by the historical circumstances of time and space on the one hand and of 'interest' on the other. In fact, the necessity of modernisation for this Moroccan nationalist is not only governed by the "spirit of the age" but also principally by "the spirit of the Sharia". This is because modernisation and development remain an urgent religious necessity with the ultimate purpose of fulfilling the principle of the vicegerency of the human being on earth (mabda'e al-Istikhlaf fi al-Arde) to 
build civilisation on the righteous grounds as the realisation of God's will. ${ }^{4}$ In this sense, whatever theorisation about modernisation should take place within the boundaries of this interest-bound thought (al-fikr al-maqassidi). Therefore, the challenge for Al-Fassi is how to make use of the significant advances of modernity without sacrificing the Islamic identity and civilisation. It is this very question of adopting modern concepts to an alien Islamic milieu with no intention of transcending the centrality of Sharia and its interests that occupies most of the writings of Al-Fassi. In An-Naqd ad-Dhati, for instance, Al-Fassi tries to formulate a coherent theory of modernisation that addresses the economy, society and politics. In so doing, he vigorously questions the extent to which the Sharia might be compatible with democracy. His reading method amalgamates the critique of Western rational paradigms, the study of the latter from the lenses of the Islamic Sharia, and finally the covering of modern concepts with what one might call a 'Sufist modernity.'

In his defence of the principles of government in Islam and human rights, Al-Fassi distinguishes between 'the social contract' and 'the Godly contract.' That is, sovereignty resides with God, yet it is the Umma who exercises sovereignty through its representatives. Hence, the organisation of the state, politics, and the public affairs belong to the interests governed by space and time, but under the umbrella paradigm of the reformulation (Ijtihad) of new government principles. This follows the historical needs of time and space imposed to bring about economic, social, and political changes, and by extension to fulfil the maslahiyat (interests) of the Umma (Hassani, 2012, p. 9). To clarify this reading paradigm, for instance, the foundational grounds of human rights stem not from "nature" but from "Providence," not from "the social contract" but from "the Godly contract," making human rights religious rights and obligations (Hassani, 2012, pp. 9-10). Unlike the social contract philosophers such as Thomas Hobbes and Jean-Jacques Rousseau, who stress that "each of us puts his person and all his power in common under the supreme direction of the general will (Rousseau, 2008, p. 55)." Al-Fassi echoes those fiqhi postulations which see the world and politics in terms of God's will, not of the general will of the people. He cannot escape conceptualising politics in terms of the often-cited Salafist ethos that "Sharia is applicable to all times and spaces." While Al-Fassi does not totally deny the human contribution to the political formation of the state and social relations, he does not decentralise the weight of God and Sharia in such a formation. This analysis confirms some confusion in the mind of this Moroccan nationalist. He views political actions both as a purely human and worldly affair and as a manifestation of God's will on earth since the principal human endeavour of people must be to work on behalf of God for the common good of the earth and its inhabitants (mabda'e al-Istikhlaffi al-Arde).

Careful consideration of interests and the maqassid remains overriding in Islamic Sharia as the ultimate purpose of legislation, including political laws and organisations. Although the Self (nafs) is central to this theory of maqassid, the political theory of Al-Fassi, unlike the liberal idolisation of the individual, favours the interest of the community of Muslims (jama 'a) over the interests of the individual, and argues for the collectivism of Islamic Sharia and the latter's struggle against individualism (1979, p. 177). As discussed above, Al-Fassi advocates some liberal tenets strongly, but he has not been able to delve into the very liberal spirit of concepts in their historical context and with a historicist reading. Instead, he positivistically borrows them shielding them with a religious and Salafist cover. Seeing such conclusions from the perspective of liberal thinkers like Thomas Paine, De Tocqueville, and Stuart Mill, Al-Fassi goes against the liberal stream, which does not defend the centrality of the interests of the community over the rights of the individuals as Al-Fassi

${ }^{4}$ This term of mabda'e al-Istikhlaf fi al-Arde is a guiding principle in Islam, which essentially applies in the Islamic worldview to every human being to the effect that he/she abides by God's decrees about establishing justice in himself and with the others. In this general sense, the human being is "God's deputy on earth." 
does. In this regard, Al-Fassi says that "the interest of the jama' $a$ must be prioritised over the interest of the individual and this is a cardinal rule that reveals the societal aspect of the Islamic Sharia and its resistance against radical individualism which allows the individual to achieve certain personal prosperity, even at the expense of society" (1979, p. 177). He extends his argumentation from the Maliki standpoint claiming that although there might appear certain balance between the individual and the community, the unity of the latter should be given priority over the rights of individuals. This sounds contradictory to the very spirit of liberalism which idolises the centrality of individuals and their liberty in social formation and political practice.

Al-Fassi always clarifies that his perspective belongs to the Salafist intellectual paradigm. In most of his books, he endeavours to simplify Salafist thought for his readers and defend the necessity of the age to adopt Salafism as a guiding principle, both to face bida ' $e$ and colonialism and to carry out the projects of modernisation. Al-Fassi defines Salafism as follows:

Salafism - in its new content as shown by Djamal ad-Din al-Afghani - is an allinclusive movement that aims to apply the principles of Islam in all aspects of human activity. It has no longer been mere purification of Islamic faith from implicit and explicit pantheism, but it has become a revival for the spirit of the Sharia with the ultimate goal of liberation, especially in the system of government, the relationship between the governor and the governed, and the relationship between power and capital. This inaugurates our struggle for a practical democracy with what it requires of liberty, equality in rights and obligations and social justice. Our battle from now on is to continue national, intellectual, and political emancipation (1999, pp. 44-5).

Al-Fassi clearly positions himself within this mainstream of struggling for democracy and human rights, but within the overriding project of reviving the spirit of the Sharia as an ultimate goal which might possibly amend the state of decadence of the nation. The political and intellectual emancipation and the key liberal concepts such as liberty, equality, and human rights are infused with a religious ideology that considers the divine and the profane as complementary. Following this logic, it is the revival of the glorious Islamic past and the teachings of the Sharia that guarantees People's emancipation in earthly matters, including political and social organisation.

In his al-Harakat al-Istiqlalya, Al-Fassi defends the fact that Morocco has a "natural predisposition", more than any other Islamic country, to accept the waves of reform enacted by the Salafist movement of reviving the 'true religion' and the Sunni creed. To defend his position, he argues that Wahhabism, being the origin and the basis for Salafism, was accepted in Morocco by Sultan Sulaymane (1792-1822). Hassan I (1873-1894) provided Sheikh Abdellah Snoussi with his protection to serve the dissemination of Salafism in Morocco; and Moulay Abdelhafid (1908-1912) played a considerable role in defending Salafist principles and fighting the bida' $e$ of the zawāy $\bar{a}$ at the beginning of the twentieth century (2003, p. 153). Al-Fassi mentions these Moroccan experiences of monarchy with Wahhabism and Salafism to legitimise his position within the Salafist framework. He stresses that "the historian of the Moroccan nationalist movement cannot ignore this critical period in the development of mentality in our country. The integration of the nationalist movement by the Salafist creed served them both to the extent that Salafism succeeded in Morocco more than it did in the lands of Abduh and Djamal ad-Din" (2003, p. 154). Such a success, Al-Fassi argues, can be attributed to the fact that this reformist movement "did not exclusively fight against the prevalence of superstition, but extends its activities to urge the people take part in radical reform that amends the stagnancy of all parts of our life" (2003, p. 155). Salafism took the form of a religious movement pretending to have political extensions that aimed at "educating the "Islamic personality" on Islamic principles for our worldly and otherworldly 
well-being" (2003, p. 156). Al-Fassi holds that "it is mandatory for Muslims to use the Sharia laws as a basis for a positivist law that certifies the establishment of a constitutional political system with the government of the people" (2003, p. 157). Although a constitutional political system might have non-Muslim origins, he insists that Salafism fosters the possibility of basing civil laws on Sharia laws. To quote him at length:

Above all, this new reformist Salafism repudiates secularism of the State, and hence Islamic government should be the guardian of morals and virtues among the members of the Umma and should prepare the best conditions and means that facilitate citizens to do their personal and social duties ... Despite whatever development might influence our civic conceptions of things, we cannot deny that Salafism has considerably influenced our psychological apparatuses, shaped our thinking, and led us to adopt such a democratic spirit (2003, p. 158).

There exists an inherent ambiguity in the mind of Al-Fassi with regards to the modern nature of the concepts he defends within the revivalist system of thought. He cannot distinguish between the historical spirit of a civilisation which still lags behind on the sideline of history and a civilisation which has monopolised the festival of change. Like other thinkers of al-Nahda, Al-Fassi advocates a hybrid perspective, conflicting or correlating, in a novel paradigm of contradictory values, and at the same time internalising this confusion and ambiguity. In this sense, his seemingly liberal ideas and conceptions have no actual bases since he endeavours to extract and deseed concepts from their context and plant them in a totally alien ground. Mohamed Abel Al-Jabri believes that "as it is always the case, ideas copied from one intellectual and social environment to another, cannot easily achieve enough supporters and, correspondingly, cannot turn into an active 'material force' in history" (AlJabri, 2011 (a), p.137). Away from the Marxist interpretation of material force, one can deduct from Al-Jabri's postulation that both the creation and advocacy of concepts need to be historically grounded in the intellectual and social environment of their production. That is, the historical spirit of the Moroccan context and the grounding of concepts within the thurati past-related paradigms prevented Al-Fassi from fully understanding and conceptualising new modern and liberal tenets. These tenets had a specific intellectual and material milieu and came into being as the inevitable consequence of a natural historical evolution, while the modern ideas newly introduced to Moroccan society under the Salafist cover remained insignificant to the masses and hence float on the surface. "This state of floating in the margin that ideas and theories went through does not result only from the underdevelopment of the Arab masses' social consciousness ... But also these ideas and theories did not start, as a point of departure, from the Arab social reality; and they did not respect its specificities. However, their content was specific to European reality" (Al-Jabri, 2011 (a), p.138). It is this very problem of concepts floating that faces Al-Fassi's intellectual project since he, like all of the al-Nahda thinkers, does not originate his seemingly liberal conceptions as ultimate result of a historical intellectual and material evolution.

The role of colonialism led Moroccan traditional intellectuals to reconsider and revisit their engagement with modernity and liberalism. Colonialism is not only a military act, but also involves a system and a process of constructing new social, intellectual and cultural systems and deconstructing the already-established systems of values. In his book Cultural Schizophrenia, the contemporary intellectual Daryush Shayegan (1997) argues that "these new ideas, revolutionary in many ways, cleared the way to other layers of reality and created other intellectual structures and social relations, most of which had not existed in our traditional world" (p. 4). Intellectuals such as Al-Fassi did not internalise the historical structural breaks of the modern age. Thus, their ideas were born in the periphery and had difficulty in coming to terms with modern ideas, particularly at the intellectual and 
ideological levels. Al-Nahda intellectuals, exemplified by Al-Fassi, usually went through "a conflictual and inter-epistemic situation" (Shayegan, 1997, p. 71), one that falls outside the monolithic vision outlined by Foucault who wrote that "in a given culture and at a given moment, there is always only one episteme that defines all the conditions of possibility of all knowledge" (Foucault, 2005, p. 183). For Shayegan, on the contrary, they are monolithic, mutually exclusive blocs each of which monopolises a given period. Different conditions can co-exist at the cost of reciprocal deformation. It is thus possible to live through a period of epistemic delay during which the adherents of an archaic episteme confront the forerunners of the world's next conceptual matrix (1997, p. 71). This, as Al-Jabri believes, resulted from the fact that "our present, along with its educational, political, social and economic issues, is a unique mixture, or a strange ensemble, of conflicting elements. It includes remnants of our past and the consequences of a present which is not ours: present of Europe" (Al-Jabri, 2011 (b), p. 36). By extension, intellectual structures of the present and the newly introduced modern concepts are not correctly contextualised within our present which still stems its theoretical paradigms from the past, as the case of Al-Fassi demonstrates. This sounds like what Shayegan calls 'intellectual schizophrenia' in which "two heterogeneous epistemes [may] operate in one and the same person, blinding him and paralysing his critical faculties" (Shayegan, 1997, p. 72). Hence, an intellectual project may incorporate different, sometimes conflictual, modes of acquiring and arranging knowledge which may result in the incoherence and disunity of the intellectual project in itself.

From the reading of Al-Fassi's intellectual project, there appears a conscious amalgamation of moral and political perspectives in scrutinising liberal concepts and their introduction to a traditional society. In other words, Al-Fassi endeavours to ground modern and liberal concepts from a religious and ethical standpoint. In his discussion of democracy, for instance, Al-Fassi tries to theoretically ground the concept of democracy as synonymous to the concept of Shura emerged during the first decades of Islamic civilisation. In his attempt to formulate a theory of what he calls 'Islamo-democratic Shura,' Al-Fassi sees that although they are not necessarily identical, democracy and Shura mimic and implicate each other to a great extent. "The focus of Muslim societies nowadays," he stresses, "should be directed to the reviving of the basic principles of their religion and making them the guiding principles in their worldly life. It is no wonder that they must look for the necessary means of the Islamic Shura from the Koran to establish a democratic system in an Islamic context" (1962, p. 96). The central question that occupied the political thought of Al-Fassi is: "Can Islamic states make use of their modern democratic political systems to revive the spirit of the Islamic Shura?" (1979, p. 118). He targets the extent to which Sharia (as-Siyassa al-Shar 'iya) may "accept" democratic paradigms of government. Generally, he considers government affairs as the primary "public interest" which remains open to reform according to the demands of time and space and the conditions of social life, thus calling the Muslims to adopt the modern and liberal means of government, from a constitutional organisation of power to the advocacy of liberty of individuals and communities, or what is called as democracy (1962, p. 96). However, Al-Fassi conditions such an adoption of democracy with the conservation of the principles of the Islamic Shura which can by any means be transcended in both legislation and political practice.

Al-Fassi deems the Shura as an indivisible part of the Sharia and provides a critical reading for this concept within the realm of his theory of Maqassid al-Sharia. The central objective of the Shura, he holds, is to raise and advance the position of the Umma and to bring the Godly Sharia into perfection on earth. This ushers the Muslim Umma to make liberty and Shura its guiding principles (1966, p. 112). Although there might exist a considerable theoretical endeavour to spot similarities between the Shura and democracy, he seems to resort to the same fiqhi paradigms and conceptual understandings such as ahl alhalwa al- 'aqd and the Shura council, in order to make sure that the political practice of the 
system of government abides by the verdicts of God. The purpose of the Shura, Al-Fassi writes, is to "supervise the governor since the latter cannot act on his own without referring back to the verdicts of God and with deliberating with the people of 'high opinion,' in Muslim community" (1985, p. 97). He continues to mimic the same legislative ideas of Muslim 'ulama of the first centuries of the Islamic civilisation. That is why the farthest intellectual horizon that Al-Fassi can reach is delimited within the realm of what he calls 'Islamic democracy.'

\section{CONCLUSION}

The intellectual project of Allal Al-Fassi faithfully mimics the intellectual and ideological projects of other al-nahda thinkers who followed the path of revivalism and Salafism. Such ideology had no clear modern theory of the state and of liberalism although it might cover its discourse and conceptions with the adoption of modern and liberal jargon. Laroui (2006) convincingly argues:

In order to know whether a writer is Salafist or a liberal, we need to ask the following question: what is his attitude towards the function of the Sharia in society? The liberal thinker considers the social organisation and interest as it is theorised based on reason and only reason, while the Salafist does not put any governing principles above those set by the Sharia rule (135).

Therefore, we cannot deny Al-Fassi's right to dream of a liberal and democratic State in which constitution, liberty, and sovereignty of the people prevail. However, this dream disclosed itself within the revivalist and Salafist system of thought. He similarly theorised about the possible ways whereby his nation could engage with modernity and lead the process of modernisation in order to both surmount the hegemonic reality of colonisation and prepare the nation-state for the post-condition of colonialism. It is true that Al-Fassi, embodying the Salafist writer, courageously moved forwards rejecting the dogmatic intellectual paradigms. Yet, however liberal such a movement might appear, it could not trespass the boundaries of existing religious understandings of modernity. The liberal concepts were not theoretically and intellectually grounded into the prevailing political and social systems. Rationalism and liberalism were never valid and advantageous to the Moroccan society unless they fulfilled the objectives of the Sharia. With such reasoning, AlFassi held that Maqassid al-sharia remained the umbrella paradigm that encompassed modernity and liberalism. There prevailed a particular circular centrality of concepts like the Shura, the Sharia, the Umma, and morality. In such a formulation, the individual established and strengthened psychological, social, and political ties within the affective conception of the Umma without any boundary-delimited conception of the State based on political and civic pillars. This lack of a clear-cut division between the profane and the sacred rendered the Moroccan nationalism as a reformist and modernising movement and Salafism as a revivalist ideology as two sides of the same coin. In fact, the utopia of religion and Salafism prevented Moroccan nationalists, exemplified by Al-Fassi, from an adequate understanding of modernity and liberalism in their historical and intellectual origins, and so his objective revolved basically around Islamising modernity. The intellectual project of Al-Fassi idolised Islam as a conceptual reference which can be a basis for democracy and perhaps compatible with liberalism. This discrepancy led him to fall within the realms of an exclusive ideology that did not believe in pluralism. The influence of Islam resulted in the understanding of political practice in terms of oneness mimicking the oneness of God. The conflict that the Comité d'action faced in the 1930s and Al-Fassi's long-standing conflict with Mohamed Hassan Ouazzani can be attributed to this fact of making a replica of divine spheres in worldly matters. As a matter of fact, the oneness of the leader, the centrality of morality, the 
Islamisation of democracy and modernity, and the idolisation of the Sharia were the ultimate incarnation of the ambiguity existing in the mind of the Moroccan nationalists between the religious and Sharia-based conceptions on the one hand and the secular grounds of democracy and liberalism on the other hand.

\section{REFERENCES}

Al-Alaoui, Moulay Tayeb. (2009). Tarikh al-Maghreb al-Siyassi fi al-'Ahdi al-Faransi [The History of the political Maghreb during the French Protectorate]. Casablanca: Manshorat Zawiya.

Al-Fassi, Allal. (1962). "Ussul al-Hokm fi al-Islam: al-Hokoma an-Nabawiya." al-Bayina 3. Rabat: Matba' at ar-Rissala.

----. (1966). Difa' 'an 'Ani Sharia [In Defence of the Sharia]. Rabat: Matba' at ar-Rissala.

----. (1979). Maqassid al-Sharia [The Purposes of the Sharia]. Rabat: Matba' at ar-Rissala.

----. (1985). Madkhalila al-Naddariya al- 'ama li dirassat al-Fiqh al-Islami [Introduction to the General Theory of Studying Islamic Law]. Rabat: Matba at ar-Rissala.

----. (1999). Al-Dimoqratiya and Kifaho al-Cha 'ebi al-Maghrebi min Ajliha [Democracy and the Struggle of Moroccan People for its Sake]. Rabat: Matba' at ar-Rissala.

----. (2003). Al-Harakat al-Istiqlaliya fi al-Maghreb al- 'Arabi [ndependence Movements in the Arab Maghreb]. Casablanca: Matba' at Najah al-Jadida.

----. (2008). An-Naqdo ad-Dhati [Self-Criticism]. Rabat: Matba'at al-Rissala.

----. (N. D). Al-Horiya [Liberty]. Rabat: Lajnat Ihya'e Thurat Allal al-Fassi.

Al-Jabri, Mohammed Abed. (2011.a). An Opinion: Towards Rebuilding the Issues of Contemporary Arab Thought. Beirut: Center for Arab Unity Studies.

----. (2011.b). Heritage and Modernism: Studies and Discussions. Beirut: Center for Arab Unity Studies.

Al-Kattani, Mohamed ben Jaafar. (2004). Salwat al-Anfasse [Tranquility of Souls]. Casablanca: Dar Athaqafa.

Foucault, Michael. (2005). The Order of Things. New York: Routledge, 2005.

Gaudio, Attilio. (1972). Allal el-Fassi ou l'histoire de l'Istiqlal. Paris: Alain Henry Editions.

Ghallab, Abdelkrim. (1991). Al-Mahidouna al-Khalidona [The Immortals]. Casablanca: Matba'at al-Najah al-Jadida.

----. (1976). Ta'rīkh al-Haraka al-Wațaniya al-Maghribiya: Min Nihāyat Harb al-Rīfiyya ilā I'lān al-Istiqlāl [History of Moroccan Nationalism: From the End of the Riffian War to the Declaration of Independence]. Casablanca: S.N.E.D. 
----. (1974). Malamih min ShakhssiyatAllal al-Fassi [Features from the Figure of Allal alFassi]. Rabat: Matba' at ar-Rissala.

Hassani, Ali. (2012). Allal al Fassi: al-Akhlaqwa al-Siyassa [Allal al-Fassi: Morals and Politics]. Casablanca: Matba'at al-Najah al-Jadida.

Laroui, Abdullah. (2006). Mafhoum al-Dawla [The Concept of State]. Casablanca, Centre Culturel Arabe.

----. (2009). Les Origines sociales et culturelles du nationalisme marocain. Casablanca: Centre Culturel Arabe.

Mahmoud, S. (2019). "Resistance in Postcolonial Literature with Reference to Sahar Khalifeh's Wild Thorns". International Journal of Language and Literary Studies, 1(2), 74-87.

Rousseau, Jean-Jacques. (2008). The Social Contract. London, Oxford University Press.

Shayegan, Daryush. (1997). Cultural Schizophrenia: Islamic Societies Confronting the West. Syracuse, N.Y: Syracuse University Press.

\section{$\underline{\text { AUTHOR'S BIO }}$}

Hamza Salih is an assistant professor at the English Department, Ecole Normale Superieure, University Mohamed V, Rabat, Morocco. He received his PhD in cultural studies from Mohemed V University of Rabat and benefitted from a Fulbright Doctoral Joint Co-Supervision at Towson University, Maryland, USA. He took part in many international conferences and delivered lectures in many countries, including Morocco, USA, UK, and Germany. He works and publishes on issues related to culture and Moroccan history of thought. 